

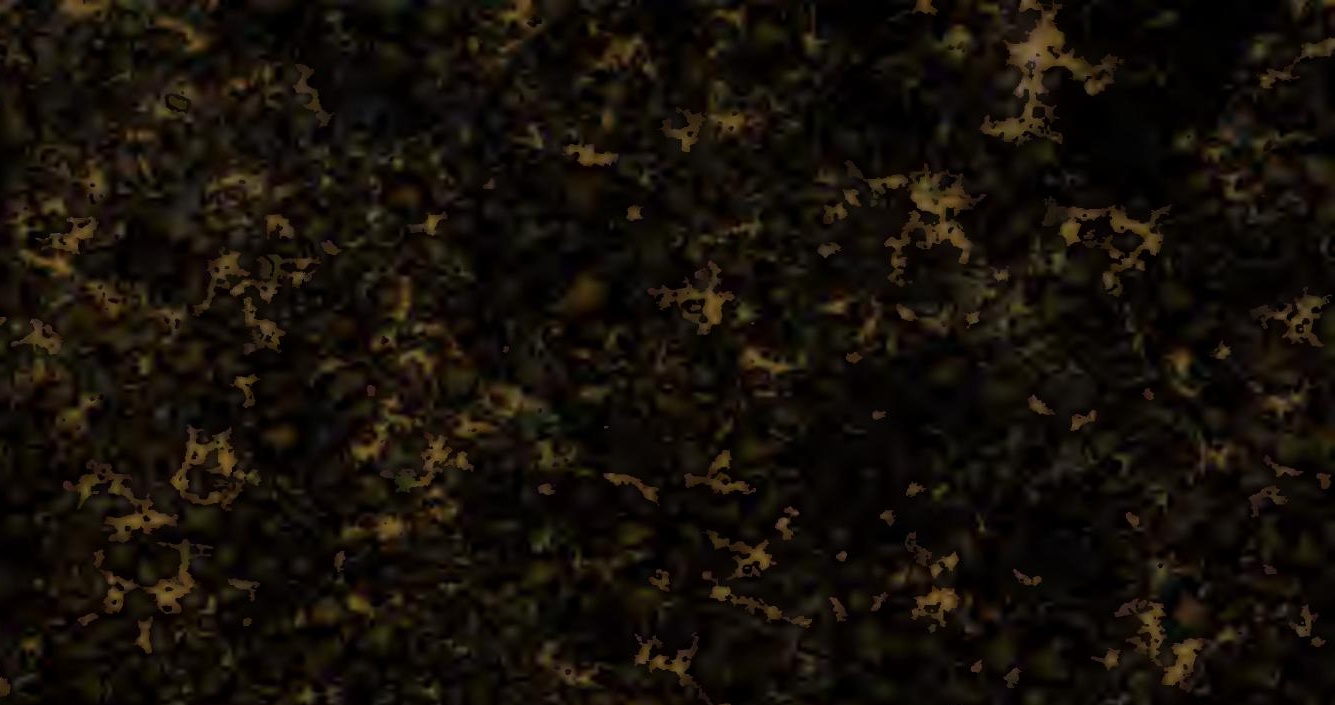

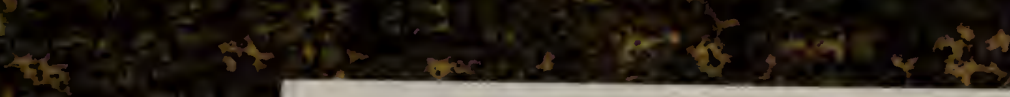

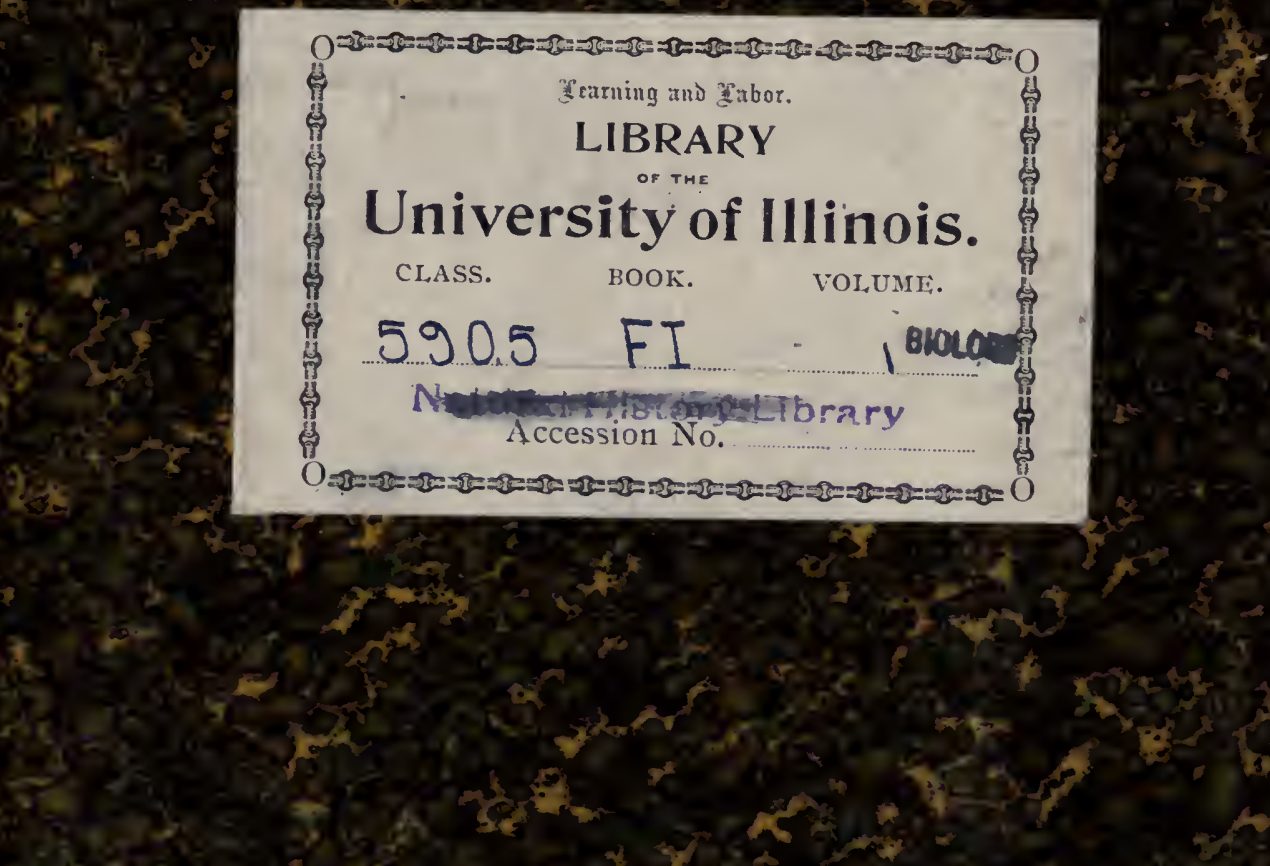

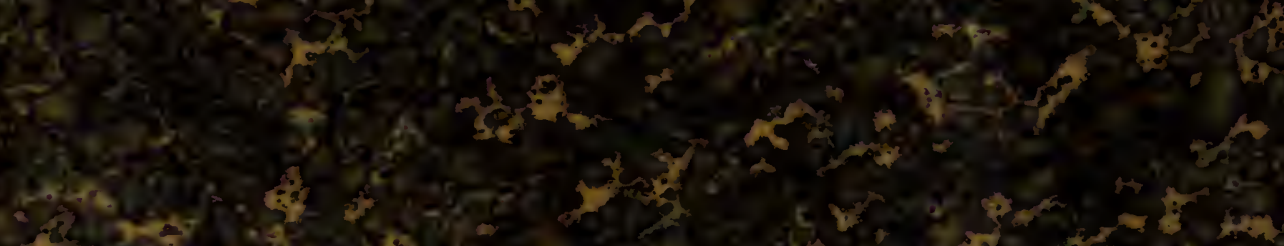

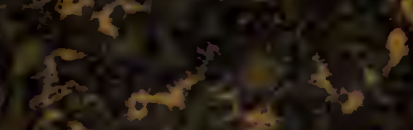

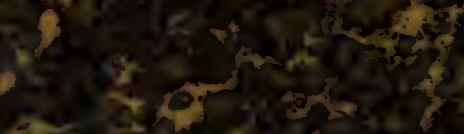
sed $x$

s. $30 x+3$ 




Field Columbian Museum

Publication 40.

Zoological Series.

Vol. I, No. I6.

\title{
LIST OF MAMMALS
}

OBTAINED BY

\section{THADDEUS SURBER,}

COLLECTOR FOR THE MUSEUM,

CHIEFLY IN

\section{OKLAHOMA AND INDIAN TERRITORIES.}

\author{
BY \\ D. G. Elliot, F.R.S.E., \\ Curator, Department of Zoology.
}

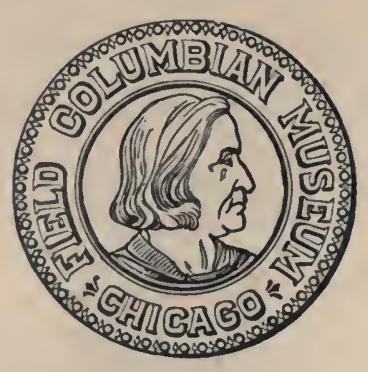

Chicago, U. S. A. October, 1899 . 



\section{LIST OF MAMMALS; FROM OKLAHOMA AND INDIAN TERRITORIES.}

BY D. G. ELLIOT, F.R.S.E.

The specimens enumerated in the following list were procured by Mr. Surber, the official collector of the Field Museum, during the past winter and spring in the two territories named, with the exception of a few obtained in the neighboring States of Texas and Kansas. The two places in which most of Mr. Surber's work was accomplished were Alva and Dougherty. The first is situated in Wood County in the northern part of Oklahoma Territory, not far from the Kansas line; the other in Indian Territory, about the center of the Chickasaw Nation. Three other places where short stays were made were Noble on the Canadian river in Cleveland County on the borders of the two territories, Arnettville in Noble County, and White Horse Springs, west of Alva. During the progress of his work Mr. Surber kept pretty full notes of the habits of the various species met with, and these have been embodied in the presont paper, and are always signed with his initials. In all something over three hundred.specimens of mammals were secured, besides a certain number of fish and reptiles.

\section{ORDER MARSUPIALIA.}

FAM. DIDELPHYID E.

Didelphys californicus.

Didelphys californicus. Bennett, P. Z. S. 1833 , p. 40.

Two adult specimens, Noble, Oklahoma Territory.

\section{ORDER RODENTIA.}

FAM. SCIURIDÆ.

Sciurus ludovicianus.

Sciurus ludovicianus. Custis, Bart. Med. and Phys. Journ. II, 1806 .

One adult female, Noble, Oklahoma Territory. 


\section{Spermophilus 13 -lineatus texensis.}

Spermophilus 13-lineatus texensis. Merr. Proc. Biol. Soc. Wash., I 898, p. 7 I.

- Twenty-four specimens. I4 Noble, 8 Alva, i White Horse Springs, I Arnettville, Oklahoma Territory.

\section{Cynomys ludovicianus.}

Cynomys ludovicianus, Ord, Guth. Geog., I817, p. 292.

Six specimens, White Horse Springs, Oklahoma Territory.

"Prairie dogs were common, located as usual in large colonies or towns. On a large perfectly level expanse of prairie, south of camp and quite near it, was a colony of several hundred Cynomys. At the time of my visit, the latter part of May and first of June, the young were just beginning to dig their own burrows which were not over one-half the size of those of the adults. Shooting these animals was very difficult until I was shown how to do it correctly, after which it became an easy matter to secure them. From their habit of sitting over the burrow, hind feet on one side, fore feet on the other, ready to drop down head first at a flash, it is almost impossible to get them, for in their dying struggles they soon get beyond reach in the almost vertical holes. However, by circling around until you can get them fairly in the back of the head with your shot, they drop hind feet foremost into the hole, and all their kicking tends to keep them up instead of pushing them down. By this method one may expect to secure specimens. There seems to be a wide variation in the color of Cynomys, individuals of several different shades being found together in the same colony. They appear to subsist wholly on the roots and stems of the buffalo grass. Some ranchmen have assured me positively that they have seen prairie dogs kill the large prairie rattlesnake, two or three of the rodents attacking it simultaneously and biting it." (T. S.)

FAM. MURID在.

\section{Onychomys leucogaster.}

Onychomys leucogaster, Wied. Reis. N. Am., I84I, p. 99.

Eight specimens. 6 Alva, Oklahoma Territory; 2 Paladura Cañon, Texas.

Altitude 3,65 o feet.

"Most of the Grasshopper Mice seemed to be either hibernat- 
ing, or to have migrated to some other region, for but few were taken, even in localities in which they were common last sum. mer. In my opinion, however, they were hibernating during the severe weather of January and February, for the few specimens secured were taken on nights when the temperature had become milder. They live in burrows very much resembling those of the Pocket Mice, but somewhat smaller." (T. S.)

\section{Peromyscus attwateri.}

Peromyscus attwateri, Allen. Bull. Am. Mus., N. Y., vii. I 895 , p. 330.

Twenty-one specimens from Dougherty, Indian Territory.

"This interesting long-tailed Peromyscus was apparently common everywhere, but especially among the loose rock on the ridges east of Dougherty. Nothing much could be learned of their habits, but they are apparently much the same as the other woodland species of the genus."

(T. S.)

\section{Peromyscus canus.}

Peromyscus canus. Mearn's Proc. U. S. Nat. Mus. Wash. I895, p. 445 .

Fifty-two specimens. I6 Alva, 20 Noble, I6 White Horse Springs, Oklahoma Territory.

The specimens from Alva are typical canus, with the long tail $66-78 \mathrm{~mm}$. in length. Those from Noble have much shorter tails, 50-69 mm., none equaling the length given for the type $75 \mathrm{~mm}$. But the general colors of the pelage are practically alike, and the skulls do not seem to differ, nor do the young. I have therefore considered them as the same. The difference, however, in the length of the tails is very conspicuous. "The white-footed mice of White Horse Spring represent either two forms, or the young and adults inhabit a different character of country, never associating together. Invariably I found the small one on the level prairies, while his big relative was always found among the rocks on the high buttes. So far as color is concerned it would be hard to distinguish them apart, but it seems strange that their habitat should be so different. Even low down on White Horse Creek I took two or three specimens among the gypsum cliffs, but no small ones were to be had nearer than the level prairie. Both may prove to be of the same species, but I shall always have my doubts owing to well marked difference in their habits." 
Sigmodon $h$. texianus.

Sigmodon h. texianus, Aud. and Bach. Quadr. III, I853, p. 229, Pl. I47, Fig. 2.

Thirteen specimens. 6 Noble, Oklahoma Territory; 7 Dougherty, Indian Territory.

"The cotton rats were all taken around the edge of a field in the river bottom one and one-half miles north of Dougherty. Apparently they were tolerably common, but from some cause would not enter traps easily. Most of them appeared to be living in old brush piles from which their runways extended in every direction. I was told they destroyed an immense amount of corn when in the shock, and that they also cut the hay in stacks very badly, particularly about the base after the manner of the meadow voles (Microtus pennsylvanicus) in the East."

(T. S.)

There is considerable difference in the total lengths of adult individuals, the measurements varying as much as twenty millimeters, and the color of the face ranged in different specimens from a dark gray through rufous to ochraceous.

\section{Reithrodontomys dychei.}

Reithrodontomys dychei, Allen. Bull. Am. Mus. Nat. His., N. Y., 1895, p. I 20.

Thirty specimens. 29 from Alva, I White Horse Springs, Oklahoma Territory.

"The little Harvest Mouse next to Cricetodipus richardsoni is the commonest small mammal found near Alva, and no matter how cold the weather it was never prevented from moving about. There were nights during my stay in Alva when the blizzard was so intensely cold that it was almost unbearable, yet on going to my traps the following day, I found some of these little fellows frozen hard as rocks in the traps, and tracks of many others in the snow. I believe this species is confined exclusively to the flat bottom land along the Salt Fork River, for I failed to secure a single individual anywhere on the prairie. During my stay at this place last summer (1898) I caught but one Harvest Mouse and it was utterly ruined by the ants which are a curse to the animal collector during the warm season."

Reithrodontomys chrysotis.

Reithrodontomys chrysotis. Elliot. Pub. Field Col. Mus., Chicago, I899, p. 281, zoology. 



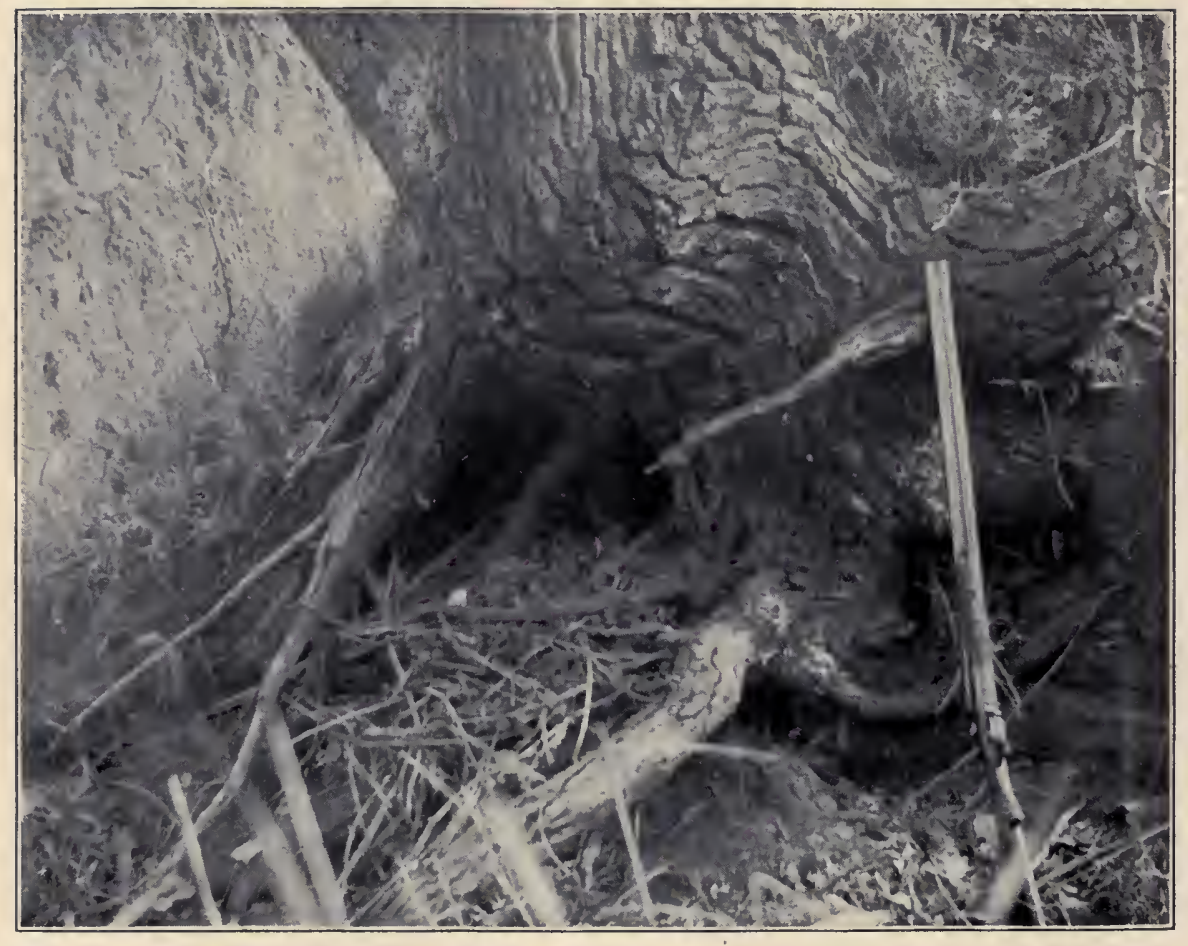

Nest of "Neotoma m. SURberi" Under Root of Cottonwood Tree. 
Three specimens from Dougherty, Indian Territory, I Noble, Oklahoma Territory.

"This interesting little mouse was taken along the edges of the cotton fields among the dense small growth of vines, bushes, etc., and as all were taken in the same character of surroundings, I am led to believe it prefers this to the more open fields, as do most of the species of this genus. One specimen was secured one and one-half miles northeast of Dougherty. The specimen taken at Noble, O. T., in March was also secured in the woodland at the edge of a cotton field. It must be a rare species, as particular pains were taken at Dougherty to secure a series, but without any success beyond the three specimens." (T. S.)

\section{Neotoma macropus surberi.}

Neotoma macropus surberi. Elliot, Pub. Field Col. Mus., Chicago, I, I899, p. 279, zoology.

Twenty-five specimens. 23 from White Horse Springs; 2 cañon 3 miles west of Alva, Oklahoma Territory.

Two specimens of this new wood rat were first obtained by Mr. Surber near Alva, and one of these served as the type of the subspecies. Subsequently Mr. Surber procured twenty-three more at White Horse Springs, west of Alva on the borders of Wood and Woodward counties. The series of examples bear a remarkably close resemblance and there is but little difference between the adults and young, the latter exhibiting a slightly deeper blue gray. It is a very handsome animal, the fur is soft as spun silk and it can readily be distinguished from any of its relatives.

"This beautiful wood rat here called locally 'Pack Rat', was first taken on February 2oth and on the following day another was secured, the female. The day on which I took the first specimen was perhaps the most delightful to me of any in my whole field experience, though it was a bitter cold day, the thermometer registering 12 below zero. I had been tramping for two weeks with this rat as my object, going the rounds of my traps in blizzards fully one-third of the time, but all the while thinking it must be $N$. baileyi, and when at last I secured the first specimen and saw how different it was from any wood rat with which I was acquainted, my joy can better be imagined than described. I first saw signs of the presence of Neotomas in a small but deep cañon two miles west of Alva, where they had a large nest built in the hollow of a large cottonwood tree. 
One of the traps set at this nest was carried off by a rascally Prairie Wolf, presumably with a wood rat in it. About a week later, in a ravine a mile further west, I found an immense fallen, hollow cottonwood tree, literally packed full of sticks, etc. Pulling and punching at this mass, the young man who was with me finally ran a large rat out, which quickly disappeared in a hollow limb of the same tree, but not before I could see it was of a bluish gray color. Having no axe with me, I was compelled to give up the chase, but returned the next day and set some Schuyler Rat Killers in and about the trees. On looking around after setting these traps, I found about roo yards lower down the 'draw' a nest of this rat, or another one. Out of the hollow tree where I first found the rat, the male was taken in a trap set at the front entrance to the nest. Not more than 30 feet from this nest stood a large partially decayed cottonwood, full of holes, and this tree I am positive held more of the rats, as well worn runways led from it to this nest and the bark was much worn on the side of the tree from the animals climbing up it, but although I kept traps set continually around and near the tree and nest until my departure several days later, I got no more Neotomas. I took a photograph of this nest and measured it accurately. It was built under the spreading branches and within a few feet of the base of a large cottonwood tree and was five feet in diameter by two feet in height. Though composed mainly of sticks, some of large size, and leaves, there was a large amount of other material in it, such as many pieces of prickly pear cactus and heads of the sumach, sand burrs, horse, cow and coyote manure, etc. Being very compactly built, I should imagine it would cause considerable exertion on the part of a coyote or badger to tear it open. There were three entrances to the nest near the ground, one near the base of the tree and the other two showing in the photograph. Each entrance was about five inches in diameter, but slightly broader than high. The nest was against the base of the ravine's wall among the grass, and sprouts of some species of 'gum-bark' bush, the sprouts showing perfectly white where they had been denuded of their bark by the rats. From the nest several smoothly worn runways extended in as many directions, some going up the ravine through the tall, rank grass which forms a roof to the runway quite up to the fallen tree where the male was taken, a distance of fully one hundred yards. Another runway leads up the back of the ravine to the level prairie above. This 


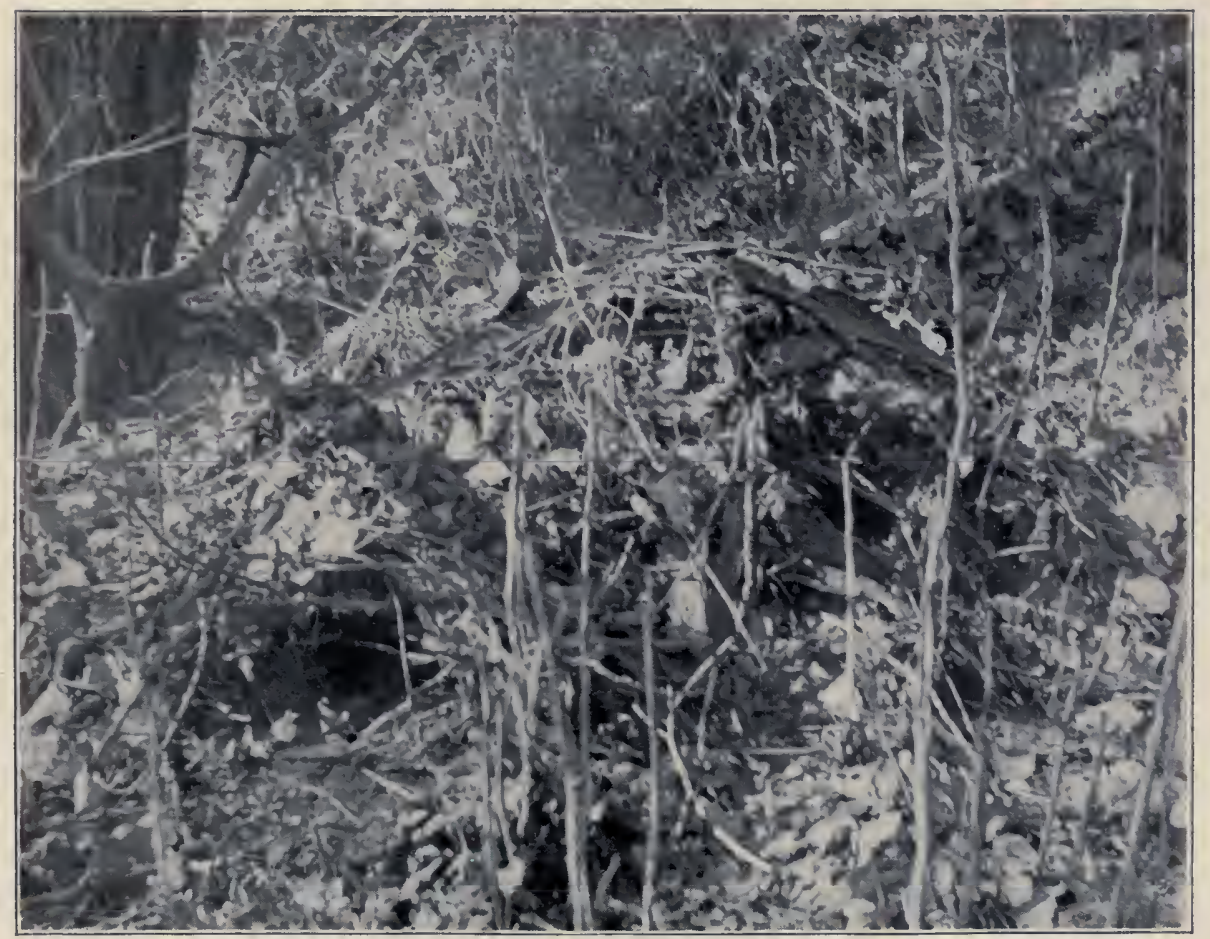

"HAYCOCK" Nest of "NeOtoma M. SURBERI" from WhICh the Type Was Taken. 

rat must be rare, as everyone to whom I showed the two specimens assured me they had never seen any like them. My trip to White Horse Springs was principally for the purpose of securing a series of this interesting form, and I am happy to say I succeeded in securing 23 specimens of various ages and sizes. The country about White Horse is broken up by deep ravines with here and there rocky buttes, some of them being fully roo feet high. These buttes are of many and curious shapes, some being perfect cones, while others look like immense houses with a chimney at one end; such, for instance, being 'Chimney Butte' two and one-half miles north of the spring. All of these high buttes have a deep ledge of rock, a sort of reddish sandstone, near their summits, forming cliffs in some places 20 feet high. Lower down on White Horse Creek there are deep cañons, crowned with cliffs of gypsum rock, with here and there caves of considerable size. Evidently these gypsum cliffs had at some time previous to my visit been favorite haunts of Neotomas, but they were about abandoned as living places at the time of my visit, though at some former time they must have been great resorts from the immense piles of sticks found there. I caught but 3 specimens in these cliffs, all the others being taken in cliffs on the high buttes quite near where I camped. Into the crevices of these cliffs the rats had carried immense piles of sticks, cactus and dried grass and sage; but nowhere did I find any of the haycock style of nests such as those near Alva, 20 miles east. From all that I could learn of their food habits they seemed to subsist mainly on green and dried grass, seeds of sumach, and seeds of cactus. In fact this was about all they could get in this semi desert region. Among the loose rock under the cliffs the Neotomas had well-beaten runways among the thick growth of weeds and sage. This formed usually a roof over the runways, and I found these to be about 5 inches in diameter on an average. I believe this form of rat to be strictly nocturnal, as I was never able, even by long, patient watching, to see one in day-time. From all that I could learn I also believe them to be migratory to the extent of changing from summer to winter quarters, even though their migrations extend for only a very short distance. That the Neotoma magister Baird of the Alleghany Mountains so migrates I have positive proof, though their migrations are irregular and depend to some extent on the food supply; and I believe this may account for the scarcity of Neotoma m. surberi among the "Gyp" cañons low down" on White Horse Creek, 
which they had deserted for higher cooler buttes. At one place I took a male and female (adults) and 3 young, which probably represented an entire family, but usually no more than one was taken in a place. My second visit to White Horse Spring, was made for the purpose of crossing into the hills 20 or 25 miles southwest of that point and south of the Cimarron River, but unfortunately on the day of my arrival at White Horse the river came down with a "head rise," and by the next day was out of its banks. I waited five days for it to fall so as to be crossed safely, but at the end of that time it showed no signs of receding, so not wishing to remain at White Horse longer I returned to Alva. I was anxious to find how far south of the Cimarron this species could be found, for from what I was told I believe its range extends to the westward from about Alva, between the Salt Fork River on the north and the Cimarron on the south. I failed to get any specimens east of Alva, so believe it ranges no farther east than that point."

(T. S.)

Neotoma bayleyi.

Neotoma bayleyi. Merr. Proc. Biol. Soc. Wash., I894, p. I23.

Ten examples. 4 from Noble, Oklahoma Territory, and 6 from Dougherty, Indian Territory.

While resembling very closely in general appearance $N$. floridana Say and Ord, this rat can readily be distinguished by its shorter tail and the greater size of the molar teeth. "I found a colony of Neotomas in the cliffs east and north of Dougherty, out of which I secured five specimens. They apparently carried no sticks into their dens, as is usually the case, and might have been transient visitants to this ledge of rock. However, they had been feeding largely on the acorns of the post-oak or black jack, as gallons of the empty shells testified. The sixth wood rat was taken along a rail fence surrounding a cotton field, in a trap set in a pile of brush. From the immense number of cliffs in the Arbuckle Mountains I should judge it to be a fine locality for this species, but they were not very common near Dougherty."

(T. S.)

Microtus (Pedomys) austerus.

Microtus austerus. Le Conte Proc. Acad. Nat. Sci. Phila., I 853 , p. 405 .

Thirteen examples. Alva, Oklahoma Territory.

"Meadow voles, were found later on the river bottom and. 
on the high prairie, and from the number of runways discovered may be considered common, particularly on the prairie. This is a species I failed to get last summer ( 1898 ), or in fact to see any signs during over four weeks collecting on the same ground."

(T. S.)

Microtus (Pitymys) pinetorum nemoralis.

Microtus pinetorum nemoralis. Bailey Proc. Biol. Soc. Wash., I 898, p. 89 .

Three specimens. 2 Dougherty, Indian Territory; I Noble, Oklahoma Territory.

"I was very agreeably surprised to find this vole in the region of Dougherty, as I hardly expected to meet the subgenus here. The two specimens secured were both taken the same day and in the same general locality-the river bottom, in which I secured the cotton rats-one was taken in an open runway, the other from what I supposed to be an old mole burrow at the time the trap was set. After this I trapped industriously for this species, but failed to get any more specimens, and as the farmers thereabouts did not recognize it I am forced to believe it is rare."

(T. S.)

\section{FAM. GEOMYID压.}

\section{Geomys breviceps.}

Geomys breviceps. Baird Proc. Acad. Nat. Sci., Phil., I855, p. 335 .

Ten specimens. 8 Alva, 2 Noble, Oklahoma Territory.

"This Gopher is equally abundant on the prairie, in the sandhills and on the river bottoms about Alva; everywhere I went hundreds of their hills being in sight at one time, particularly near the river bluffs. I found their burrows everywhere from three inches to two and one-half feet below the surface, but deepest usually on the river bottom, where they worked beneath the deep, sandy, brick-like soil in the softer sand beneath. On the river bluffs in the rich black soil their burrows would average about ten inches under the surface. They are easy to catch in properly set traps, but most of the time I was in Alva, in January and February, the earth was frozen to such a depth that it was utterly impossible to dig into their runs. However, one day I set a trap and took a specimen when the thermometer registered ro below zero. In my opinion this would prove the species to be active all winter, for at this time the earth was frozen I $8-22$ 
inches deep, and inside the burrow twelve inches below the surface was white with frost." (T. S.)

\section{FAM. HETEROMYIDÆ.}

Cricetodipus richardsoni.

Dipodops richardsoni. Allen, Bull. Am. Mus. Nat. Hist. N. Y., r8gr, p. 277.

Thirty-two examples. 30 Alva, Oklahoma Territory; 2 Coolidge, Kansas.

"Kangaroo rats, or sand rats as they are called, are perhaps the most abundant small mammals found in western Oklahoma. Their center of abundance seems to be along the river bottom in the sand bars and small sand-hills where vegetation is very scant. They are also found sparingly in the sand-hills back on the prairie, but never away from the sand; as they delight in it, and from which they appropriately derive their common name. They live in colonies, and are very industrious little animals. One individual digs several holes, and by trying constantly to keep the sand clear of the burrows soon enlarges them to such an extent that many are fully six inches in diameter. This species I found active in the severest winter weather, and during my stay in their range, that night was an exception when they were not out in the snow, either digging or searching for food. During one of the severest blizzards we had early in February, I caught specimens of this species in traps and saw tracks of numbers of others in the snow, the temperature being then 22 below zero. At this season they seemed to be feeding principally on the seeds of the cockle burr and sand burr, but last August I found the seeds of the prickly pear cactus formed a great percentage of their food. In fact, these hardy desert plants are about the only thing they have to depend on, unless the so-called "bunch grass" be excepted, on the seeds of which they may also feed. That they can stand thirst for a very long period I have proved by the few I have kept in captivity. These little animals make very interesting and beautiful pets, being perfectly tame even when first caught. They can easily be taken in box traps during the summer."

\section{Perognathus (Chaetodipus), paradoxus.}

Perognathus paradoxus, Merr. N. Am. Faun. I, I889, p. 24.

Twenty-one specimens. II Alva, 6 Noble, 2 White Horse Springs, 2 Arnettville, Oklahoma Territory. 
"Pocket Mice are common about Alva, both on the bottomlands and the high prairie, but they were evidently hibernating during my stay, and but few specimens were taken, these being secured on soft days when the earth had thawed to a certain extent. They almost invariably inhabit the unbroken prairie where they make their burrows among the short buffalo grass. While the burrow of this species is equally as large and in some instances even larger than the Striped Spermophile, it can be told even at a glance by its circular form and being sunk perpendicularly to a depth of six or eight inches, whereas the Spermophile's burrow is usually slightly flattened and goes into the earth at an angle of about 30 degrees. I have almost invariably found, at a distance of from six inches to two feet from their burrow, little mounds of sand and gravel, varying in size from a quart to a half bushel, and can only account for their presence by believing that it is cast there by these mice when digging their burrows."

(T. S.)

\section{FAM. LEPORID Æ.}

\section{Lepus melanotis.}

Lepus melanotis. Mearns, Bull. Am. Mus. Nat. Hist. N. Y., I 890 , p. 299.

One specimen, White Horse Springs, Oklahoma Territory.

\section{Lepus alacer.}

Lepus alacer. Bangs Proc. Biol. Soc., Wash., I896, p. I36. Two specimens, Alva, Oklahoma Territory.

"This hare is very abundant among the willow brush and high grass along the Salt Fork River bottom.lands, but so far as I could learn was replaced on the prairies by a smaller species which frequents prairie dog towns, living in deserted burrows of these rodents. This species is one of the fleetest runners of the cotton tail group, and unless a greyhound has a fair open field, it will outrun the dog every time. In my opinion they are much fleeter than the Lepus melanotis, and harder to get a shot at. The two specimens secured were taken in Schuyler Rat Traps baited with corn and set for 'Sand Rats.' Some were caught in steel traps but were unfit for specimens. In some small sand-hills east of the river, but in the bottom land, this hare was very common among the sage-brush, but they usually left their forms before I could get in shotgun range and only afforded me a glimpse of their cottony tails before disappearing. 
They are found in all the cañons and creeks emptying into the Salt Fork near Alva, but seldom go far out on the prairie."

Lepus telmalemonus.

Lepus telmalemonus. Elliot, Pub. Field Col. Mus., I899, p. 285, zoology.

Two specimens, Dougherty, Indian Territory.

FAM. MUSTELIDE.

Spilogale interrupta.

Mephitis interrupta. Rafinesque Ann. Nat., I820, p. 3.

Five specimens, Alva, Oklahoma Territory.

"Little striped skunks are very common everywhere about Alva, being perhaps more numerous in the Kangaroo Rat colonies along the river. I imagine their main dependence for food is this rat, whose burrow requires but little digging on Spilogale's part to effect an entrance, as the skunk's body is very slender. In fact, nearly all the specimens I obtained were taken in what I supposed to be the Kangaroo Rat burrows, and in every case but one they were caught in Schuyler Rat Killers. These traps will not kill. a Spilogale, for every one secured was caught fairly around the neck just back of the head, and they were very lively indeed when I went to take them out, and I was compelled to silence their abrupt manner of greeting with a load of dust shot from my auxiliary barrel. Their odor is very bad, being, in my opinion, more disagreeable than that of the common skunk."

(T. S.)

Mephitis mesomelas.

Mephitis mesomelas, Licht. Darst. N. Säug., pl. 45, fig. 2.

Two specimens, six miles east of Alva, Oklahoma Territory.

"The local name for this species is 'Hydrophobia Cat,' and its bite is believed to give one symptoms of hydrophobia, which I was assured often proved fatal. All the specimens secured were excessively fat."

(T. S.)

Taxidea berlandieri.

Taxidea berlandieri. Baird Mam. N. Am. I857, p. 205.

One specimen, 6 miles east of Alva, Oklahoma Territory.

This single example was the only one obtained by Mr. Surber, although every effort was made to procure a number. The accompanying photograph, taken while the animal was held by the trap, gives a very good idea of its appearance in life. 


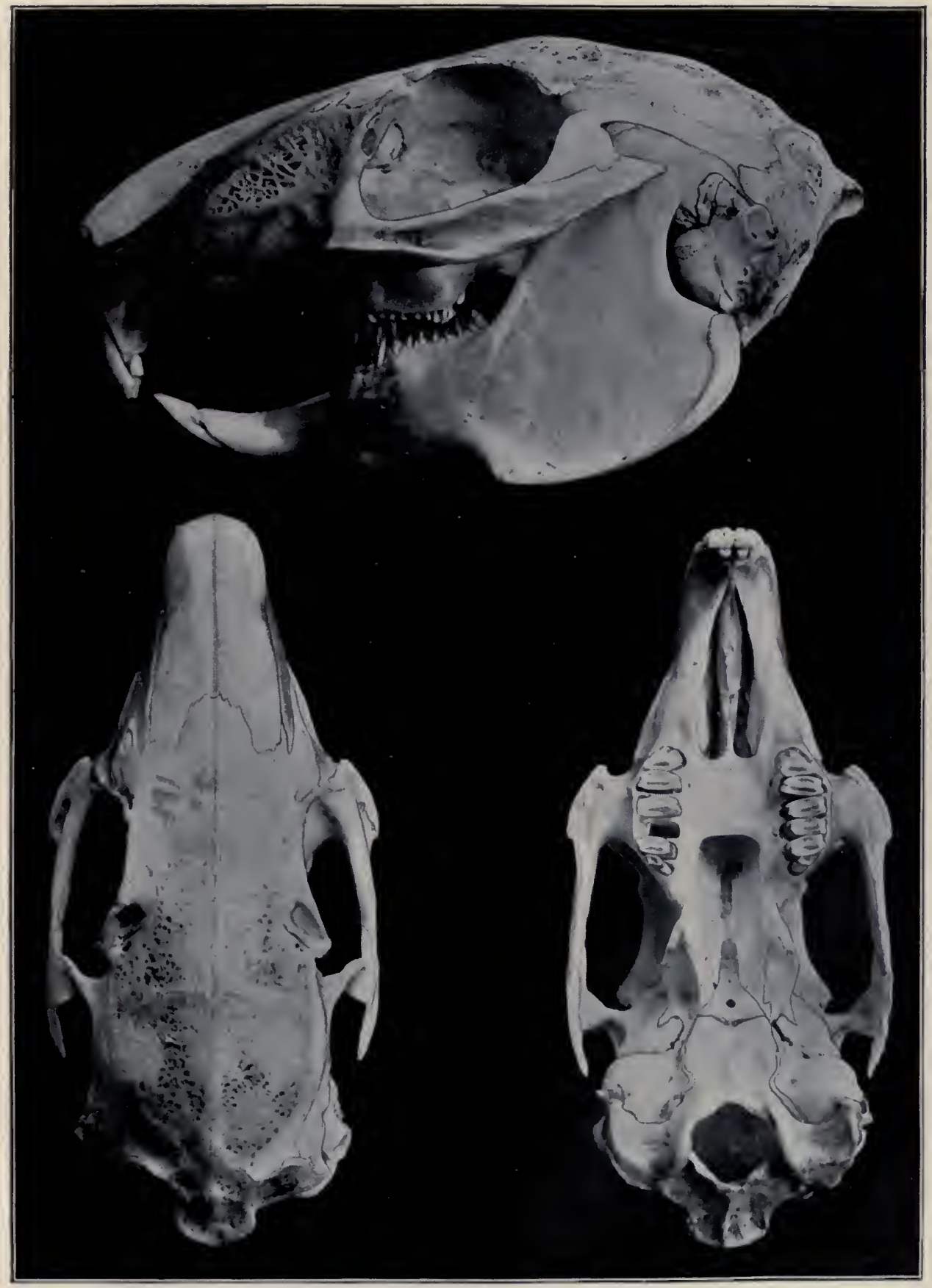






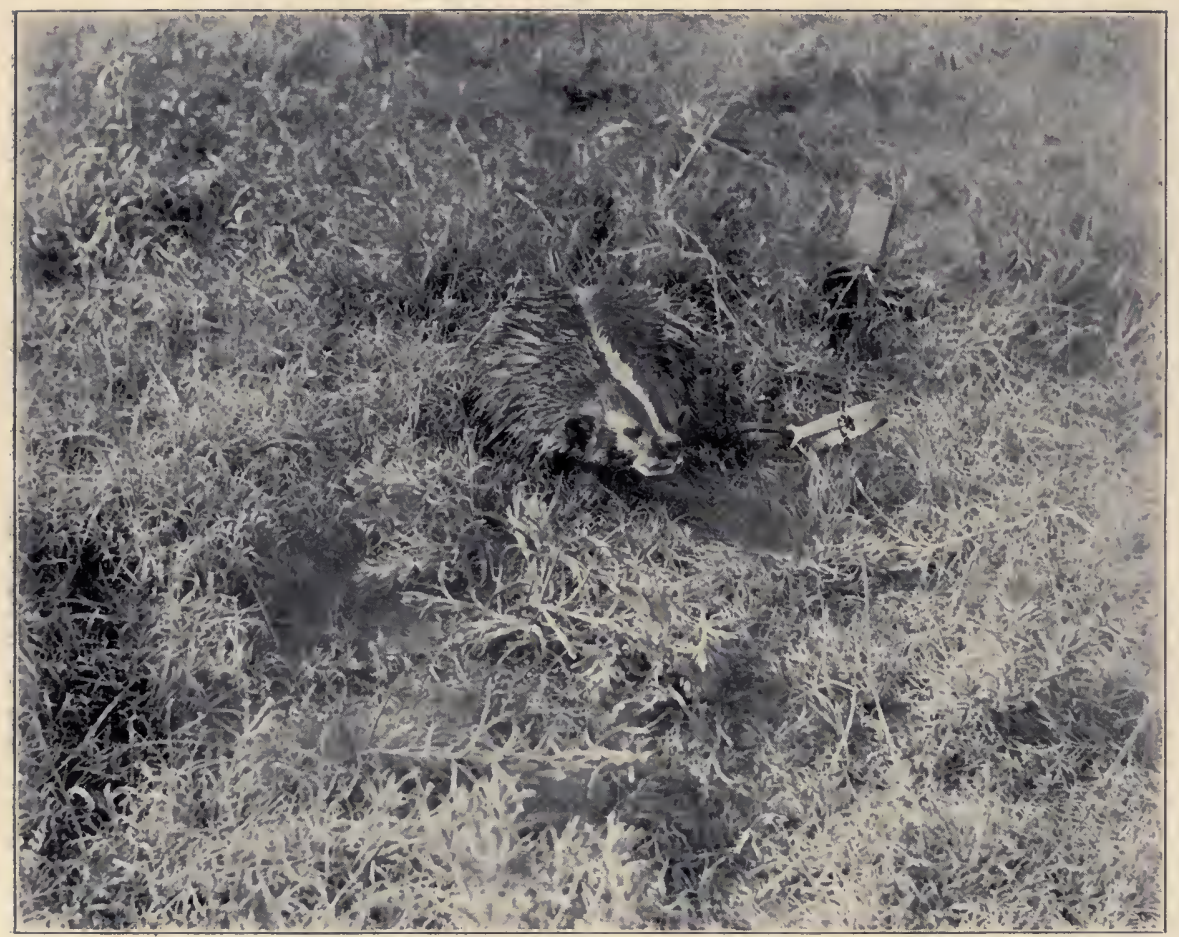

A Trapped Badger. 
"Badgers are not very common at White Horse; in fact, I failed to see a single fresh hole, and it seems strange that they were not found in the vicinity of the prairie dog towns. A lack of their favorite food-the Spermophiles-may to some extent influence their distribution. East of Alva they are quite common, and it was here I secured the fine female sent to the Museum. This badger had dug three immense holes the night before I caught it, and in one of them it was taken in a trap which I had carefully concealed in the loose dirt well down in the burrow. I never saw a more furious animal, and it gave me no end of trouble before I finally secured its photograph. The burrow I opened, looking for young badgers, extended back for twenty feet, at a depth of four feet under the surface, and I am positive was the result of only a few hours' digging. The soil in that place, however, was a loose, black loam." (T. S.)

\section{ORDER INSECTIVORA.}

\section{FAM. TALPID死.}

\section{Scalops machrinus intermedius.}

Scalops m. intermedius, Elliot, Pub. Field Col. Mus., Zool., I 899, p. 280 .

Seven examples. 6, Alva, Oklahoma Territory; I, Dougherty, Indian Ter.

This is one of the handsomest of the moles and is probably not rare in the territories where the specimens were obtained, but the weather was decidedly unfavorable and this probably was the reason that so few were taken.

"The weather was very cold during my stay at Alva, and the ground was so frozen I obtained but few moles. They are, however, common about this region and apparently do most of their work in the broken fields, where they have no tough soil to contend with. In an alfalfa field I traced one runway 80 paces or about 225 feet, and during this time noticed perhaps as many as fifty short side runs, extending from the main one. In Indian Territory this mole is common everywhere about Dougherty, but luck seemed against my securing more than one specimen. I could find no trace of its presence on the hills anywhere," (T. S.)

Blairina brevicauda hulophaga.

Blairina b. hulophaga. Elliot, Pub. Field Col. Mus., I899, p. 287, Zoology.

Two specimens. Dougherty, Indian Territory. 




